\title{
7 Guidelines for Contributors
}

Technostyle invites manuscripts dealing with subjects of interest to readers involved in business, technical, academic, professional, scientific and governmental communication, as teachers, practitioners or researchers. A wide range of approaches to the study of non-literary communication is entertained by Technostyle-rhetorical, linguistic, sociological, cultural, enthographic - but all submissions should be securely situated in relevant research. While manuscripts addressing pedagogical issues are welcome, authors should avoid describing lessons without explaining their significance to broader theoretical concerns. Technostyle also welcomes articles which place these concerns in a context specific to relevant scholarship in Canada.

Manuscripts should be no longer than 6500 words / 25 double spaced typed pages and should be submitted in two copies free of internal or external indications of identity of author(s). All manuscripts will be externally reviewed, and authors may be asked to undertake revisions in response to reviewers' evaluations.

The editor also invites submissions which respond to articles published in Technostyle. These submissions will be incorporated into the Forum section of the journal and should be no longer than 500 words. Publication will be subject to editorial decision.

Authors of accepted submissions will be asked to conform to APA style in citations and headings, and to provide a disk as well as a hard copy of the final version of articles and "Comment" pieces. Submissions must be made on a 3.5 inch disk formatted for DOS in any version of Microsoft Word, up to 6.0, and any version of Wordperfect, up to 5.1 .

Technostyle welcomes manuscripts in both French and English.

Articles and manuscripts should be sent to:

Diana Wegner, Editor

Technostyle

Department of English and Communications

Douglas College

P.O. Box 2503

New Westminster, B.C.

V3L 5B2 


\title{
$\checkmark$ Guide à l'intention des auteurs
}

Technostyle accepte des manuscrits portant sur des sujets d'intérêt pour les lecteurs - professeurs, praticiens ou chercheurs — dont les activités touchent la communication (commerciale, technique, professionnelle, scientifique, gouvernementale, etc.). La revue accepte diverses approches (rhétorique, linguistique, sociologique, culturelle, ethnographique) de la communication non littéraire, mais les études proposées doivent s'appuyer sur des recherches pertinentes. Les auteurs d'articles traitant de questions pédagogiques doivent dépasser le cadre purement pratique et placer les enseignements proposés dans un contexte théorique. Technostyle accueille aussi volontiers des articles qui situent ces questions pédagogiques dans le cadre de la recherche poursuivie au Canada dans ce domaine.

Les manuscrits ne doivent pas dépasser 6500 mots (25 pages tapées à double interligne); ils doivent être fournis en deux exemplaires et ne doivent comporter aucune indication explicite ou implicite de l'auteur ou des auteurs. Tous les articles sont soumis à un comité de lecture qui peut demander aux auteurs d'effectuer des remaniements.

La rédaction invite les lecteurs à soumettre, en réponse à des articles publiés dans Technostyle, des commentaires qui ne doivent pas dépasser 500 mots; la rédaction se réserve le droit de les publier ou non.

Il est demandé aux auteurs dont les textes sont acceptés pour publication de respecter, pour les titres et les citations, le protocole de rédaction de l'APA (American Psychological Association); ils sont priés de faires parvenir une copie manuscrite de la version finale des articles ou des commentaires ainsi qu'une copie sur disquette 3.5" formatée en DOS pour Microsoft Word 6.0 (ou version antérieure) et pour Wordperfect 5.1 (ou version antérieure).

Les articles peuvent être présentés en anglais ou en français.

Prière d'adresser les manuscrits à l'adresse suivante:

\author{
Diana Wegner, Editor \\ Technostyle \\ Department of English and Communications \\ Douglas College \\ P.O. Box 2503 \\ New Westminster \\ V3L 5B2
}

